\title{
Use of $N, N^{\prime}$-diacetylchitobiose in decreasing toxic effects of indoor air pollution by preventing oxidative DNA damage
}

\author{
Neeta A. Salgaonkar ${ }^{1}$, Prasad M. Thakare ${ }^{1}$, Manisha V. Junnarkar ${ }^{1}$, \\ Balasaheb P. Kapadnis ${ }^{2}$, Abul Mandal ${ }^{3}$, Cecilia Eriksson ${ }^{4} \&$ Neelu N. Nawani ${ }^{1}$ \\ 1 Microbial Diversity Research Centre, Dr. D.Y. Patil Biotechnology and Bioinformatics Institute, Dr. D.Y. Patil \\ Vidyapeeth, Pune-411033, India; e-mail: neelunawani@yahoo.com; neelu.nawani@dpu.edu.in \\ ${ }^{2}$ Department of Microbiology, Savitribai Phule University of Pune, Pune - 411007, India \\ 3 System Biology Research Centre, School of Biosciences, University of Skövde, SE-54128 Skövde, Sweden \\ ${ }^{4}$ School of Biomedicine, University of Skövde, Skövde, Sweden
}

\begin{abstract}
Indoor air pollution occurs due to hazardous pollutants, such as tobacco smoke, pesticides and carbon oxides, sulphur oxides and nitrogen oxides arising from combustion of biomass fuels. Exposure to these pollutants results in respiratory conditions like asthma, chronic obstructive pulmonary disease, lung cancer, pneumonia and other lower respiratory infections. Several of these infections are a result of inflammation and oxidative stress. Here we demonstrate the ability of $N, N^{\prime}$-diacetylchitobiose in preventing oxidative DNA damage in peripheral blood mononuclear cells exposed to biomass smoke extracts and cigarette smoke extract. The cytotoxic effect of these pollutants was determined by trypan blue exclusion assay in peripheral blood mononuclear cells, where cytotoxicity in decreasing order was cigarette $>$ wood $>$ sawdust $>$ cowdung. Cytotoxicity could be due to single- and double-strand breaks in the DNA as a result of oxidative stress. Comet assay measures the extent of DNA damage in the cells exposed to toxic agents. When mononuclear cells were treated with $N, N^{\prime}$-diacetylchitobiose and later exposed to smoke extracts, the extent of DNA damage decreased by $44.5 \%$ and $57.5 \%$ as compared to untreated cells. The protection offered by $N, N^{\prime}$-diacetylchitobiose towards oxidative DNA damage was at par with quercetin, a popular herbal medicine. Glutathione-S-transferase activity was determined in mononuclear cells exposed to smoke extracts, where oxidative stress in cells exposed to cigarette smoke extract was maximum. The present study demonstrates for the first time the ability of $N, N^{\prime}$-diacetylchitobiose to alleviate the harmful effects of indoor air pollutants.
\end{abstract}

Key words: $N, N^{\prime}$-diacetylchitobiose; comet assay; indoor air pollution; biomass smoke; cigarette smoke; cytotoxicity; glutathione-S-transferase.

Abbreviations: BSEs, biomass smoke extratcs; COPD, chronic obstructive pulmonary disease; COS, $N$-acetylated chitooligosaccharides; CSE, cigarette smoke extract; DMSO, dimethyl sulfoxide; (GlcNAc) $)_{2}, N, N^{\prime}$-diacetylchitobiose; GST, glutathione-S-transferase; IAP, indoor air pollution; LPG, liquefied petroleum gas; OS, oxidative stress; PBMCs, peripheral blood mononuclear cells; PBS, phosphate buffered saline; ppm, parts per million; ROS, reactive oxygen species; SCGE, single cell gel electrophoresis; WHO, World Health Organization.

\section{Introduction}

Cooking practices in rural communities and poor urban settlements are largely based on the use of solid biomass fuels, such as wood, coal, dried leaves, cowdung, crop residues, etc. (Bruce et al. 1998). In 2009 World Health Organization (WHO) had reported indoor air pollution (IAP) as tenth major cause of death globally, and first amongst environmental risk factors. More than 4.3 million people die every year by inhalation of indoor smoke due to burning of unprocessed biomass fuel as reported by WHO in 2014. This largely compromises the quality of health although the consequences are avoidable. Traditional cook-stove (Chulha), being a part of rural kitchen, adds up the burden of cocktail of pollutants like particulate matter, carbon monoxide, nitrogen dioxide, sulphur dioxide, volatile organic compounds, polycyclic aromatic hydrocarbons and free radicals leading to IAP by burning of these biomass fuels (WHO 2000, 2011). These pollutants are at least 50 times more noxious than liquefied petroleum gas (LPG) (Smith 2003). The majority of population like women, young children and elderly people are more vulnerable to toxic effects of biomass fuel smoke as they spend most of their time indoors (Smith 1993). It is well known that biomass smoke and cigarette smoke induced IAP is potentially responsible for a range of diseases, i.e. chronic obstructive pulmonary disease (COPD) (Ceylan et al. 2006),

\footnotetext{
* Corresponding author
} 


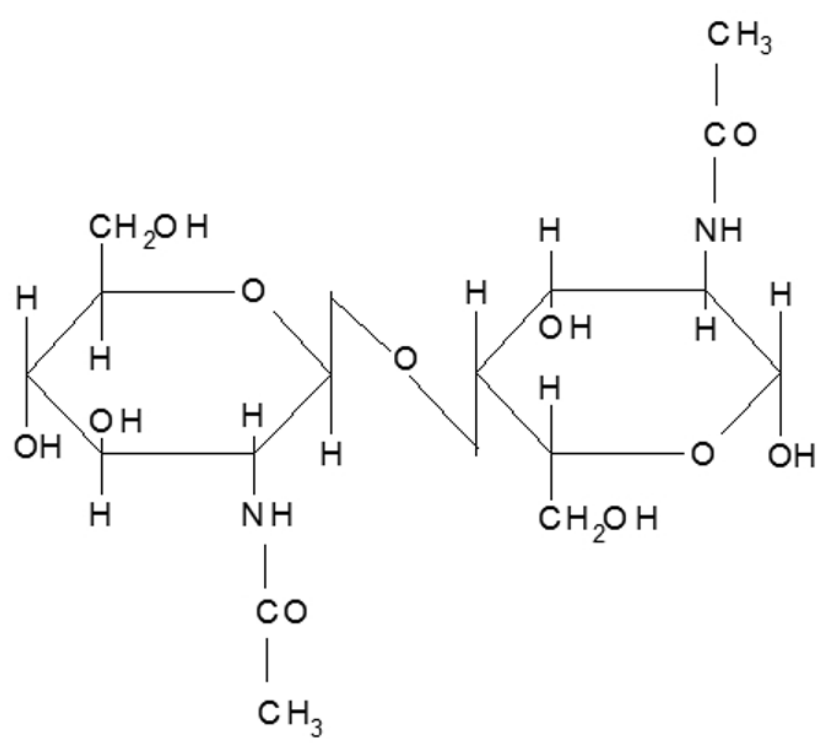

Fig. 1. Structure of $(\mathrm{GlcNAc})_{2}$.

lung cancer (Smith \& Liu 1994), asthma, cardiovascular diseases, cataracts, tuberculosis (Balkrishnan et al. 2004; Smith et al. 2004; Fullerton et al. 2008) and other acute lower respiratory infections (Smith et al. 2000) mainly due to inflammation and oxidative stress (OS). Reactive oxygen species (ROS) produced due to OS affect human health and damage vital macromolecules in the body, such as nucleic acids, carbohydrates, proteins and lipids. Cigarette smoke extract (CSE) mediated OS is mainly because of the production of $\mathrm{H}_{2} \mathrm{O}_{2}$ (Downs et al. 2011). $\mathrm{CO}$ and $\mathrm{SO}_{2}$, being the principle components of wood, cowdung and cigarette smoke, contribute significantly to the IAP. CO toxicity has been studied by many and DNA damage due to effect of $\mathrm{CO}$ has already been reported (Hopkins \& Evans 1980; Ozturk et al. 2002; Slezak et al. 2014). The effect of $\mathrm{SO}_{2}$ on male and female reproductive toxicity is well documented, where exposure to $\mathrm{SO}_{2}$ [(100-400 parts per million (ppm)] led to immediate danger of death. Low concentrations $(<40 \mathrm{ppm})$ increased the morbidity and mortality rate in few cases and changed lung function (Campbell et al. 2011).

$N, N^{\prime}$-diacetylchitobiose (GlcNAc) $)_{2}$ (Fig. 1), the dimer of $N$-acetylglucosamine is reported for antiinflammatory (Wang et al. 2009), antimicrobial (Liang et al. 2007), anti-angiogenic, immune stimulating (Wang 2010), antioxidant (Chen et al. 2003; Nawani et al. 2010; Azam et al. 2014) and DNA damage protecting ability (Ngo et al. 2010; Salgaonkar et al. 2015).

We have previously demonstrated the protective function of $N$-acetylated chitooligosaccharides (COS) towards oxidative DNA damage induced by hydrogen peroxide, where $(\mathrm{GlcNAc})_{2}$ offered $59.5 \%$ protection to peripheral blood mononuclear cells (PBMCs) (Salgaonkar et al. 2015). Therefore, the protective nature of $(\mathrm{GlcNAc})_{2}$ encouraged us to assess its ability to reduce the toxic effects of IAP due to oxidative stress. It is reported that chitotriosidase and acid mammalian chitinase produced by humans result in production of (GlcNAc) 2 (Boot et al. 2001; Prakash et al 2013). These enzymes are elevated in lung inflammatory conditions suggesting a possible natural role of $(\mathrm{GlcNAc})_{2}$ that can be further explored to develop therapeutic agents for lung diseases (Létuvé et al. 2010). Besides, chitin bio-waste can serve as a natural resource for the enzymatic extraction of (GlcNAc) $)_{2}$ (Nawani et al. 2010).

Pollutants like $\mathrm{CO}, \mathrm{SO}_{2}, \mathrm{NO}$ and $\mathrm{NO}_{2}$ arising from biomass combustion and cigarette smoke were trapped in organic solvent. PBMCs were exposed to these pollutants and their cytotoxicity was determined. The protective ability of (GlcNAc) $)_{2}$ ( $\geq 96 \%$ purity) towards oxidative DNA damage induced by biomass smoke extracts (BSE) and CSE was estimated. The glutathioneS-transferase (GST) as a biomarker of oxidative stress was also evaluated by estimating its activity in PBMCs exposed to cowdung smoke extract and CSE. The possible preventive role of $(\mathrm{GlcNAc})_{2}$ has not been studied so far in any research for reducing the dangerous effects of IAP.

\section{Material and methods}

\section{Materials}

$($ GlcNAc) 2 (purity $\geq 96 \%$ ), low melting point agarose, dimethyl sulfoxide (DMSO) and sarcosine were purchased from Sigma Aldrich (St. Louis, MO, USA). $\mathrm{H}_{2} \mathrm{O}_{2}(50 \% \mathrm{v} / \mathrm{v})$, quercetin, GST and trypan blue dye $(0.4 \%)$ were procured from HiMedia Laboratories Pvt. Ltd. (Mumbai, India). All other chemicals specified were of highest analytical grade and obtained from Thermo Fischer Scientific (Mumbai, India). Biomass, such as wood and sawdust, cowdung cakes and commercial hard-tar cigarette (Marlboro, Philip Morris, Inc., Richmond, VA, USA, containing $10 \mathrm{mg}$ tar and $0.8 \mathrm{mg}$ nicotine) were purchased from local market.

Determination of emission levels of carbon, sulfur and nitrogen oxides from biomass smoke, cigarette smoke and LPG IAP was recorded in terms of flue gases generated by burning of wood (sawdust and wood), cowdung and commercial hard tar cigarette. The flue gases were analyzed for CO, $\mathrm{SO}_{2}, \mathrm{NO}$ and $\mathrm{NO}_{2}$ emissions by a portable flue gas analyzer (Testo-350, Testo Ltd., Hampshire, UK). The analysis was carried out in real time by Testo easy emission software with a measure rate of $5 \mathrm{~s}$. Sawdust, wood and cowdung $(0.2 \mathrm{~g}$ each) and cigarette (butt length $3 \mathrm{~cm}$ ) were burnt in a crucible for $15 \mathrm{~s}$ and the flue gases emitted were measured at a distance of $10 \mathrm{~cm}$ from the source. The measurements were recorded by using a gas sensor probe attached to Testo-350 control unit for $2.30 \mathrm{~min}$, the time required to turn the complete biomass $(0.2 \mathrm{~g})$ into ash. Ambient air and LPG were kept as controls.

\section{Preparation of BSEs and CSE}

BSEs were prepared by the method of Bolling et al. (2012) with slight modifications. The extracts were freshly prepared, immediately before use, by separately burning $0.2 \mathrm{~g}$ of sawdust, wood and cowdung. Smoke from each source was collected in an inverted glass tube for $3 \mathrm{~min}$ and was reconstituted in $1 \mathrm{~mL}$ of $0.2 \%$ DMSO at room temperature. This stabilizes ROS generated and solubilises waterinsoluble lipophilic compounds. This suspension was further 
sonicated in an ultrasonic water bath for 20 min to prepare a homogenous mixture. The BSEs were then filtered through a $0.22 \mu \mathrm{m}$ pore filter. This solution was an undiluted BSE and further used for assays. Smoke from commercial hightar cigarette (Marlboro brand) was collected for 3 min and treated in the same way as that for BSE and was referred to as CSE.

\section{Cytotoxicity of BSEs and CSE by trypan blue dye exclusion} assay

The cytotoxicity of BSEs and CSE was analyzed by determination of cell viability using trypan blue dye exclusion assay. PBMCs with cell density $2 \times 10^{6}$ cells $/ \mathrm{mL}$ were exposed to undiluted BSEs and CSE for $1 \mathrm{~h}$ at room temperature. After $1 \mathrm{~h}$ exposure, PBMCs were washed by centrifuging at $130 \times g$ for $5 \mathrm{~min}$ and resuspended in $10 \mu \mathrm{L}$ PBS. The number of viable cells were determined based on membrane integrity where $10 \mu \mathrm{L}$ of cells were stained with $10 \mu \mathrm{L}$ of trypan blue dye $(0.4 \%)$ and incubated for $4 \mathrm{~min}$ at room temperature. The cells were observed and counted using Neubaur's chamber at $400 \times$ magnification. The percent cell viability for each treatment was expressed in the form of number of viable cells with respect to total cells by the following formula:

$\%$ viable cells $=$ (number of viable cells $/$ total number of cells) $\times 100$

Assessment of DNA damage in PBMCs exposed to BSEs and CSE by comet assay

The toxic effects of BSEs and CSE were assessed in PBMCs by a method of alkaline comet assay, as described by Singh et al. (1988) and Holz et al. (1995) with minor modifications described by Salgaonkar et al. (2015). Briefly, a single cell suspension of PBMCs was prepared, treated with undiluted BSEs and CSE for $1 \mathrm{~h}$ at room temperature to induce DNA damage. The cells were centrifuged at $130 \times g$ for 5 min after exposure to BSEs and the pellet formed was washed twice with phosphate buffered saline (PBS). The cells obtained were further used for determination of extent of DNA damage. The vehicle control was included in the assay, where cells were treated with $0.2 \%$ DMSO only to minimize the endogenous DNA damage. To optimize the method, preliminary dose-response studies were carried out with $100 \mu \mathrm{M}$ of $\mathrm{H}_{2} \mathrm{O}_{2}$ as oxidant and (GlcNAc) ${ }_{2}$ (Salgaonkar et al. 2015).

Determination of protective effects of $(G l c N A c)_{2}$ in PBMCs against BSE and CSE

To investigate the protective effect of (GlcNAc) 2 against BSE and CSE, PBMCs were first treated with $100 \mu \mathrm{M}$ (GlcNAc) $)_{2}$ for $10 \mathrm{~min}$ at $4{ }^{\circ} \mathrm{C}$, centrifuged at $130 \times g$ for $5 \mathrm{~min}$, and pellet was washed twice with PBS. The cells were then exposed to BSE and CSE for $1 \mathrm{~h}$ at room temperature. After exposure, PBMCs were washed with PBS and comet assay was performed as described above. Quercetin $(10 \mu \mathrm{M})$ as positive control and (GlcNAc) $)_{2}$ alone $(100 \mu \mathrm{M})$ (Salgaonkar et al. 2015) were included for its known protective effect against $\mathrm{H}_{2} \mathrm{O}_{2}$-induced DNA damage.

\section{Quantitation of comets}

All the treatments were performed in triplicates. The slides were prepared and observed under a fluorescent microscope (Olympus CX41, Hamburg, Germany) after 15 min of staining at $100 \times$ magnification, which was attached to a ProgRes C3 camera connected to a computer. The DNA damage was calculated in fifty randomly selected individual cells by using ImageJ analysis software v1.48 with OpenComet 1.3 as plug-in (Gyori et al. 2014). The most common comet parameter, i.e. the percent DNA in tail was selected to express the DNA damage in the form of DNA fragments formed in the tail region of cell by the formula as follows:

$$
\begin{aligned}
& \% \text { DNA in tail }=(\text { tail DNA intensity } / \text { cell DNA intensity }) \\
& \times 100
\end{aligned}
$$

\section{Estimation of GST activity}

GST activity estimation kit (CCK028, Himedia EZAssay ${ }^{\mathrm{TM}}$ ) was used for this assay to estimate the activity of GST in PBMCs $\left(2 \times 10^{6}\right.$ cells $\left./ \mathrm{mL}\right)$ exposed to BSEs and CSE for $1 \mathrm{~h}$ at room temperature. This kit was based on the conjugation of 1-chloro-2,4-dinitrobenzene with reduced glutathione that produces a dinitrophenyl thioether, which can be detected at $340 \mathrm{~nm}$. After $1 \mathrm{~h}$, cell lysates were prepared as per protocol mentioned in the kit and supernatant obtained was tested for GST activity. Initially the assay buffer and sample buffer from the kit were diluted $(1: 2)$ as per method described in the kit. The amount of $930 \mu \mathrm{L}$ assay buffer was used to set the spectrophotometer to zero. To this, $10 \mu \mathrm{L}$ of glutathione and $10 \mu \mathrm{L}$ of substrate solution were added, mixed and the absorbance was read at $340 \mathrm{~nm}$ after every 1 min to obtain 6 readings referred to as blank readings. Six $\mu \mathrm{L}$ of the GST standard was added to above substrate mixture for positive control and for the test samples (cell supernatants from each treatment). Fifty $\mu \mathrm{L}$ of these supernatants were thoroughly mixed with above substrate mixture and absorbance was read at $340 \mathrm{~nm}$ every $1 \mathrm{~min}$ to get 6 readings referred to as test readings. The GST activity was calculated based on the following formula mentioned in the protocol:

GST activity $(\mu \mathrm{mole} / \mathrm{mL} / \mathrm{min})=\left[\left(\Delta \mathrm{A}_{340} / \mathrm{min} \times 1\right) /\right.$ $(9.6 \times 0.05 \mathrm{~mL})] \times$ sample dilution factor,

where $\Delta \mathrm{A}_{340}=$ change in absorbance $\left(\Delta \mathrm{A}_{340}\right)$ per min; $1 \mathrm{~mL}=$ reaction volume; $9.6 \mathrm{mM}^{-1} \mathrm{~cm}^{-1}=$ extinction coefficient for test (glutathione-2,4-dinitrobenzene adduct) in cuvette (path length $=1 \mathrm{~cm}$ ); $0.05 \mathrm{~mL}=$ sample volume.

\section{Statistical analysis}

The flue gas analysis was performed in triplicates. The results from the analysis were expressed as mean \pm standard deviation of three measurements $(n=3)$. The data derived from comet assay and cell viability by trypan blue dye exclusion experiments was subjected to one way Analysis of Variance (ANOVA) followed by Tukey's multiple comparisons test by using GraphPad Prism 6.0 (GraphPad Prism software, USA). The test criterion for statistical significance was $p<0.05$. The GST activity data was displayed as mean \pm standard error of three measurements $(n=3)$. The graphs were plotted using Origin 6.0 statistical software.

\section{Results and discussion}

Determination of emission levels of carbon, sulfur and nitrogen oxides from solid biomass fuel smoke, cigarette smoke and $L P G$

Flue gas analysis from biomass and cigarette at a distance of $10 \mathrm{~cm}$ in controlled conditions indicated significantly higher $\mathrm{CO}, \mathrm{SO}_{2}, \mathrm{NO}$ and $\mathrm{NO}_{2}$ emission levels than LPG. Table 1 illustrates the emission levels of these gases from biomass (wood, sawdust, cowdung) 
Table 1. Analysis of $\mathrm{CO}, \mathrm{SO}_{2}, \mathrm{NO}$ and $\mathrm{NO}_{2}$ from biomass smoke (wood, sawdust, cowdung) and cigarette smoke.

\begin{tabular}{|c|c|c|c|c|c|c|c|c|}
\hline \multirow{2}{*}{ Biomass smoke } & \multicolumn{4}{|c|}{ Flue gases [Max-Min (ppm)] } & \multicolumn{4}{|c|}{ Flue gases $\left[\right.$ Mean $\left.(\mathrm{ppm})^{a}\right]$} \\
\hline & $\mathrm{CO}$ & $\mathrm{SO}_{2}$ & NO & $\mathrm{NO}_{2}$ & $\mathrm{CO}$ & $\mathrm{SO}_{2}$ & NO & $\mathrm{NO}_{2}$ \\
\hline Ambient air & $0.1-0.0$ & 0.0 & 0.0 & 0.0 & $0.1 \pm 0.05$ & 0.0 & 0.0 & 0.0 \\
\hline LPG & $5.0-0.0$ & $1.0-0.0$ & $7.0-0.0$ & $0.2-0.0$ & $2.0 \pm 0.05$ & $1.0 \pm 0.5$ & $3.0 \pm 1$ & $0.1 \pm 0.05$ \\
\hline Sawdust & $6798.0-122.0$ & $11.0-0.0$ & $0.76-0.0$ & $37.66-0.0$ & $2173.0 \pm 697.0$ & $6.33 \pm 4.0$ & $0.16 \pm 0.05$ & $14.66 \pm 0.6$ \\
\hline Wood & 1935.5-1.5 & 0.0 & $16.5-0.0$ & $0.2-0.0$ & $854.0 \pm 379.0$ & 0.0 & $7.5 \pm 3.5$ & $0.05 \pm 0.07$ \\
\hline Cowdung & $3916.3-170.6$ & $11.0-0.3$ & $0.2-0.0$ & $0.6-0.0$ & $2258.3 \pm 202.0$ & $7.0 \pm 1.0$ & 0.0 & 0.0 \\
\hline Cigarette & $5865.0-98.6$ & $53.3-0$ & $128.6-2.6$ & $0.36-0.0$ & $3115.0 \pm 530.0$ & $30.3 \pm 4.04$ & $90.0 \pm 9.84$ & 0.0 \\
\hline
\end{tabular}

${ }^{a}$ The ppm values mentioned above were from mean $\pm \mathrm{SD}$ of three replicates.

and cigarette. The concentrations of the gases are expressed as ppm and mean \pm standard deviation of three replicates for ease of comparison. These toxic substances emitted were compared with that from ambient air and LPG. Exposure to such harmful emissions leads to mutagenecity or genotoxicity causing damages in DNA. In the present study, the emission levels of CO and $\mathrm{SO}_{2}$ from smoke are in the order of cigarette $>$ cowdung $>$ sawdust $>$ wood. Cowdung has not shown any $\mathrm{NO}$ and $\mathrm{NO}_{2}$ emissions. Our study indicated increase in the levels of $\mathrm{CO}(3,455 \mathrm{ppm}), \mathrm{SO}_{2}(30 \mathrm{ppm}), \mathrm{NO}$ $(90 \mathrm{ppm})$ and no change in $\mathrm{NO}_{2}(0 \mathrm{ppm})$ from cigarette (butt length $=8.3 \mathrm{~cm}$, burnt $=3 \mathrm{~cm}$ in $2.30 \mathrm{~min}$ ) than cowdung $\mathrm{CO}(2,390 \mathrm{ppm}), \mathrm{SO}_{2}(7 \mathrm{ppm}), \mathrm{NO}$ and $\mathrm{NO}_{2}$ $(0 \mathrm{ppm})$ by flue gas analyzer at a distance of $10 \mathrm{~cm}$ in tube method. Higher levels of emissions would be observed if more number of cigarettes are burnt for longer duration in a day.

$\mathrm{CO}, \mathrm{SO}_{2}, \mathrm{NO}$ and $\mathrm{NO}_{2}$ in sawdust smoke were 2,173, 6.33, 0.16 and $14.66 \mathrm{ppm}$, respectively, and 854, $0,7.5$ and $0.05 \mathrm{ppm}$, respectively, for wood smoke. Wood smoke had lower levels of $\mathrm{CO}, \mathrm{SO}_{2}, \mathrm{NO}$ and $\mathrm{NO}_{2}$ than sawdust smoke. Since these results were obtained in controlled conditions, the emission levels of these obnoxious gases will vary depending upon the time of exposure, type and amount of biomass, humidity, etc. All the above values were higher as compared to LPG, which gave $2 \mathrm{ppm} \mathrm{CO}, 1$ ppm $\mathrm{SO}_{2}, 3$ ppm NO and $0.1 \mathrm{ppm} \mathrm{NO}_{2}$. To maintain uniformity throughout the experiments, all measurements were carried out by burning the biomass $(0.2 \mathrm{~g})$ and cigarette $(3 \mathrm{~cm})$ for $15 \mathrm{~s}$ and readings were taken for $2.30 \mathrm{~min}$ at $10 \mathrm{~cm}$ from the source.

Cytotoxicity of BSEs and CSE by trypan blue dye exclusion assay

The cytotoxic effects of BSEs and CSE in PBMCs were evaluated by trypan blue dye exclusion assay (Fig. 2). It is well known that OS influences the cell viability (Castillo et al. 2007; Mates et al. 2012). Our results showed that number of viable cells decreased after $1 \mathrm{~h}$ exposure to smoke extracts. The viable cells were least for cigarette smoke followed by wood and sawdust smoke and were maximum for cowdung smoke indicating that cigarette smoke was most harmful. Bazzini et al. (2013) showed that CSE significantly increased cell mortality via apoptosis-

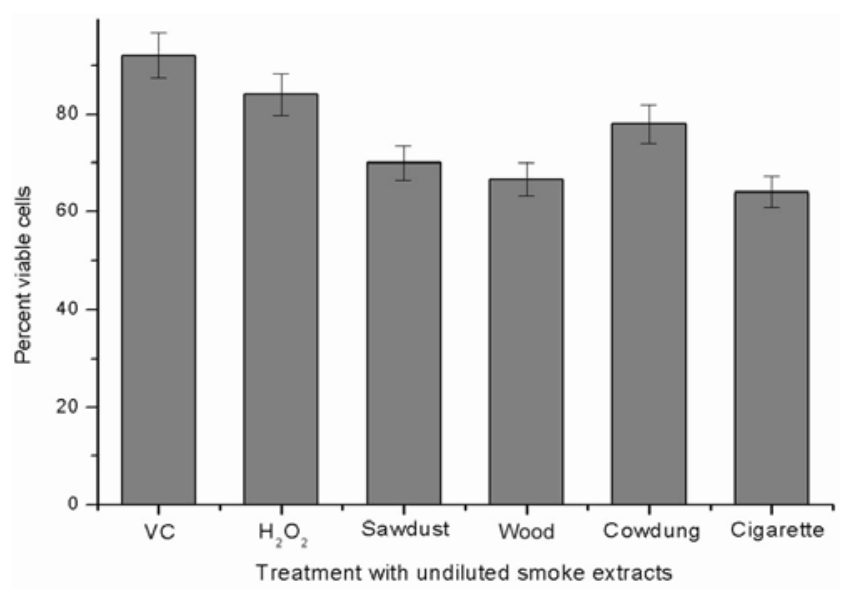

Fig. 2. Viability of PBMCs in presence of BSEs and CSEs (trypan blue dye exclusion assay). All smoke extracts were used in undiluted form. PBMCs were treated with $0.2 \%$ DMSO as vehicle control (VC); smoke extract of sawdust and wood, cowdung and cigarette for $1 \mathrm{~h}$ at room temperature. Hydrogen peroxide $(100 \mu \mathrm{M})$ was used as standard oxidant in comparison to the toxic pollutants. Cell viability was expressed as percent of viable cells with respect to total number of cells $(n=3, p<0.05)$.

independent pathway, which correlates with our CSE study.

Assessment of DNA damage in PBMCs exposed to BSEs and CSE by comet assay

BSEs and CSE were used to induce oxidative stress and $100 \mu \mathrm{M} \mathrm{H} \mathrm{H}_{2} \mathrm{O}_{2}$ was used as a standard oxidant. The comparative DNA damage in PBMCs due to the toxic effect of biomass and cigarette smoke was demonstrated (Fig. 3A,B). ANOVA followed by Tukey's multiple comparison test shows DNA damage in PBMCs due to $\mathrm{H}_{2} \mathrm{O}_{2}(82.32 \%)$, cigarette $(73.92 \%)$ and cowdung $(58.89 \%)$ smoke extracts is significant as compared to $0.2 \%$ DMSO $(8.29 \%)$ used as vehicle control $\left(R^{2}=0.99\right.$, $p<0.05)$. There is no significant change in DNA damage for sawdust and wood smoke extracts (11.63\% and $8.37 \%$ DNA in tail, respectively) as compared to vehicle control. These results were also supported by the research done by Rekhadevi et al. (2009), in which no significant DNA damage was seen in human beings even after years of occupational exposure to wood dust; in contrast more damage was seen with increasing age, or consumption of alcohol and smoking.

The DNA damage was maximum for cigarette 


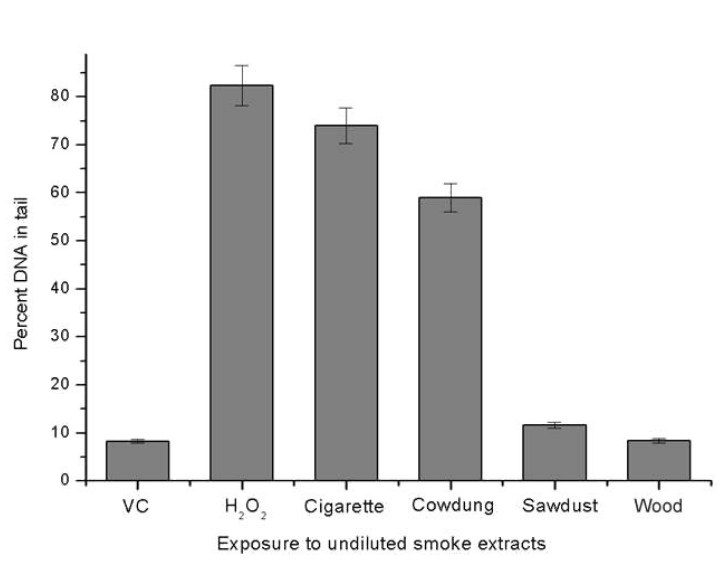

A
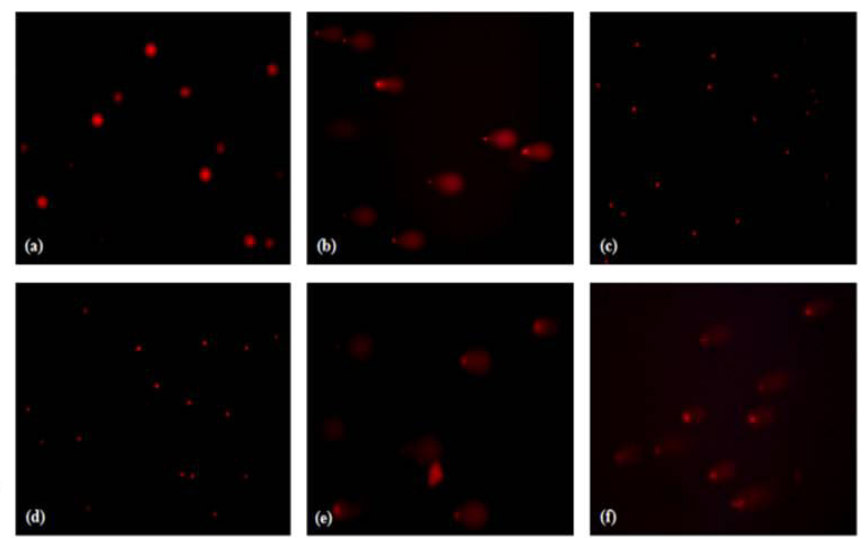

B

Fig. 3. (A) Comparative DNA damage of PBMCs exposed to $100 \mu \mathrm{M} \mathrm{H}_{2} \mathrm{O}_{2}$, cigarette smoke extract and biomass smoke extracts (cowdung, sawdust and wood). Cells were treated with undiluted smoke extracts for $1 \mathrm{~h}$ at room temperature in dark $(n=3, p<0.05)$. (B) Representative comets indicating DNA damage in PBMCs treated with (a) $0.2 \%$ DMSO as vehicle control, (b) $100 \mu \mathrm{DM} \mathrm{H}_{2} \mathrm{O}_{2}$, (c) sawdust smoke extract, (d) wood smoke extract, (e) cowdung smoke extract, and (f) cigarette smoke extract. Magnification $=100 \times$.

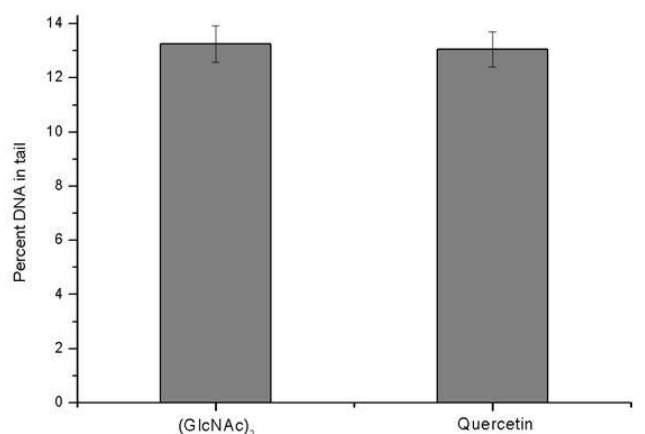

A

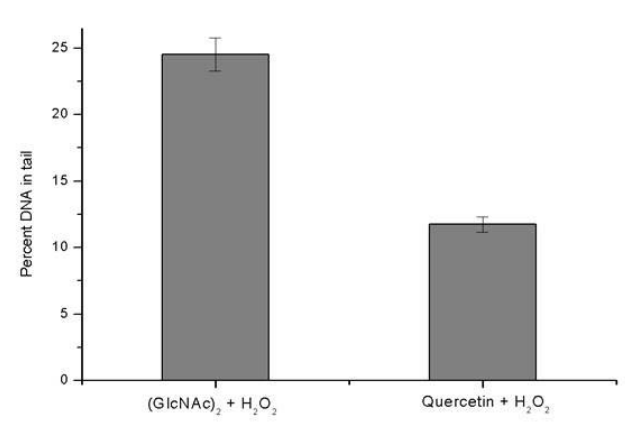

B
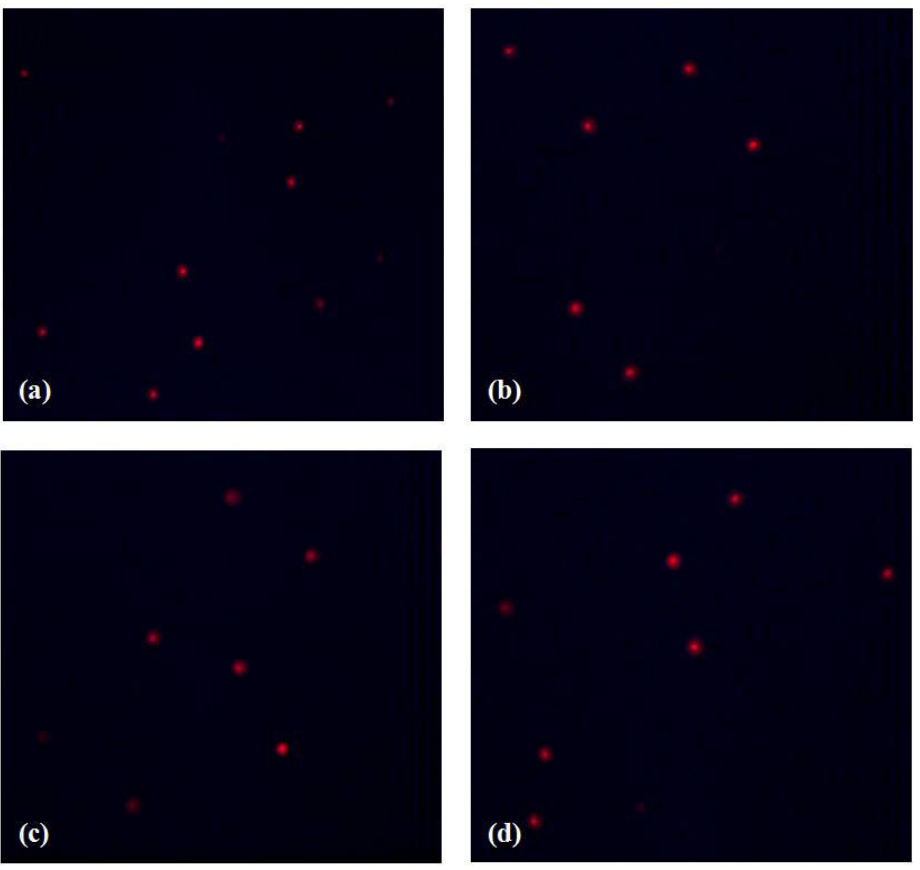

C

Fig. 4. DNA damage induced with $100 \mu \mathrm{M} \mathrm{H} \mathrm{H}_{2} \mathrm{O}_{2}$ and protective ability of (GlcNAc) 2 and quercetin in PBMCs. (A) Treatment with $100 \mu \mathrm{M}(\mathrm{GlcNAc})_{2}$ and $10 \mu \mathrm{M}$ quercetin for $10 \mathrm{~min}$ at $4{ }^{\circ} \mathrm{C}$ in dark. (B) Pretreatment with $100 \mu \mathrm{M}(\mathrm{GlcNAc})_{2}$ and $10 \mu \mathrm{M}$ quercetin and then exposure to $100 \mu \mathrm{M} \mathrm{H}_{2} \mathrm{O}_{2}$ for $10 \mathrm{~min}$ at $4{ }^{\circ} \mathrm{C}$ in dark, indicating protective effect of $(\mathrm{GlcNAc})_{2}$ and quercetin $(n=3, p<$ 0.05). (C) Representative comets when PBMCs were exposed to (a) (GlcNAc) 2 , (b) quercetin, (c) pretreatment with (GlcNAc) 2 and then exposure to $100 \mu \mathrm{M} \mathrm{H}_{2} \mathrm{O}_{2}$, and (d) pretreatment with quercetin and then exposure to $100 \mu \mathrm{M} \mathrm{H}_{2} \mathrm{O}_{2} \cdot \mathrm{Magnification}=100 \times$.

smoke followed by cowdung smoke and was least for sawdust and wood smoke. The results in this study suggest that even though sawdust and wood smoke extracts were cytotoxic to PBMCs, they did not show any DNA damage. On the other hand, cowdung smoke extract and CSE were cytotoxic and DNA damage could be seen in PBMCs exposed to them.
Assessment of possible protective effect of $(\mathrm{GlcNAc})_{2}$ towards BSEs and CSE induced DNA damage

The possible protective effect of (GlcNAc) $)_{2}$ for PBMCs exposed to cowdung smoke extract and CSE was investigated in vitro by comet assay. Quercetin is reported for its harmful (when concentration is high such as $50 \mu \mathrm{M}$ ) as well as protective effects on human 


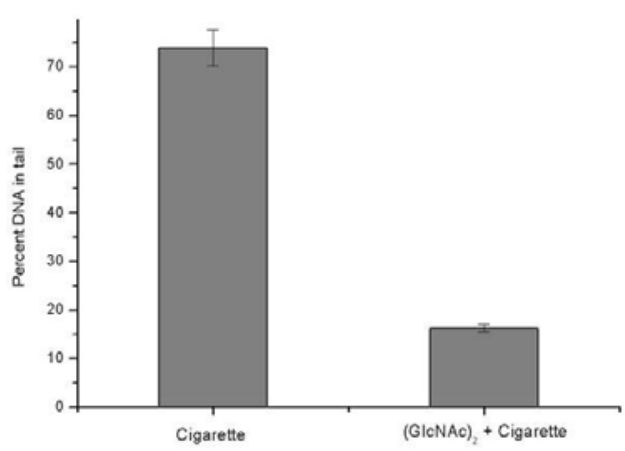

A

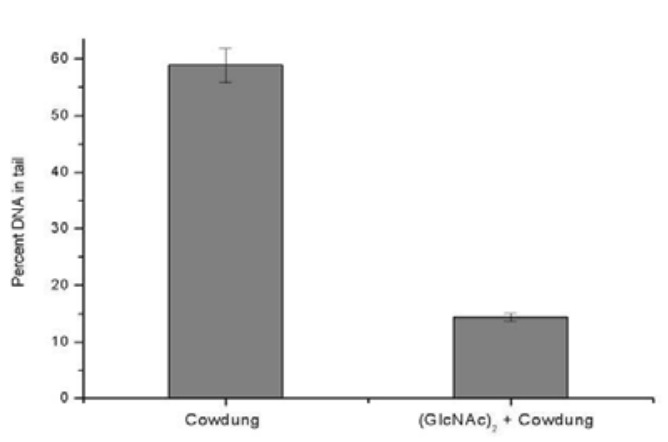

B
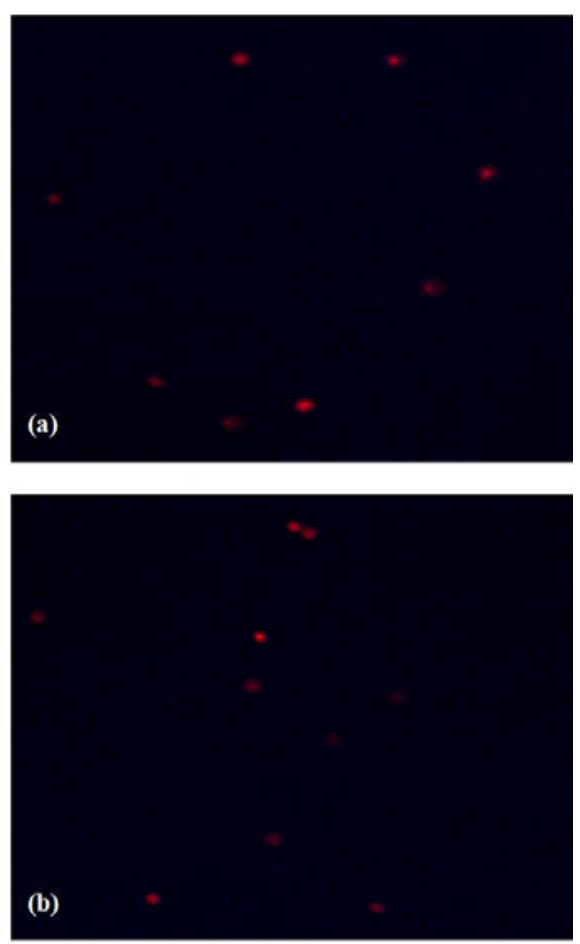

C

Fig. 5. Protection offered by (GlcNAc) 2 towards oxidative DNA damage in PBMCs exposed to cowdung and cigarette smoke. (A) Exposure to CSE versus pretreatment of PBMCs with $100 \mu \mathrm{M}$ (GlcNAc) 2 followed by exposure to CSE. (B) Exposure to cowdung smoke extract versus pretreatment of PBMCs with $100 \mu \mathrm{MM}$ (GlcNAc) 2 followed by exposure to cowdung smoke extract $(n=3$, $p<0.05$ ). (C) Representative comets for PBMCs pretreated with (GlcNAc) 2 followed by the treatments expressed in (A) and (B). Magnification $=100 \times$.

health $(\leq 10 \mu \mathrm{M})$ (Musonda \& Chipman 1998). Hence, $(\mathrm{GlcNAc})_{2}(100 \mu \mathrm{M})$ was compared with quercetin $(10 \mu \mathrm{M})$ for any induction of DNA damage when $\mathrm{H}_{2} \mathrm{O}_{2}$ was used as an oxidant. There was no significant difference between (GlcNAc) 2 and quercetin, as both did not induce DNA damage greater than $13 \%$ (13.25\% and $13.05 \%$ DNA in tail, respectively) for cells that were not exposed to any oxidant (Fig. 4A, Ca, Cb). When PBMCs were separately treated with (GlcNAc) $)_{2}$ and quercetin, and exposed to $\mathrm{H}_{2} \mathrm{O}_{2}$, DNA damage respectively decreased to $24.51 \%$ and $11.74 \%$ DNA in tail as compared to $82.32 \%$ damage induced by $\mathrm{H}_{2} \mathrm{O}_{2}$ alone (Fig. 4B,Cc,Cd). When PBMCs were treated with (GlcNAc) $)_{2}$ and then exposed to cowdung smoke extract and CSE, the DNA damage respectively decreased to $14.4 \%$ and $16.33 \%$ DNA in tail (Fig. 5A,B); and the comets formed are shown in Figure $5 \mathrm{Ca}, \mathrm{Cb}$ for the respective treatments as indicated above. The report published by Ngo et al. (2010) correlates with our findings: there was a decrease in oxidative DNA damage of human lymphoma U937 by COS with molecular weight ranging from 229.21 to 593.12. In this study, sawdust and wood did not cause significant DNA damage, so they were not selected for (GlcNAc) 2 protection experiments. These results are supported by the study of Forchhammer et al. (2012), who demonstrated that no significant DNA damage occurs when cells are exposed to controlled wood smoke for $3 \mathrm{~h}$. One way Analysis of

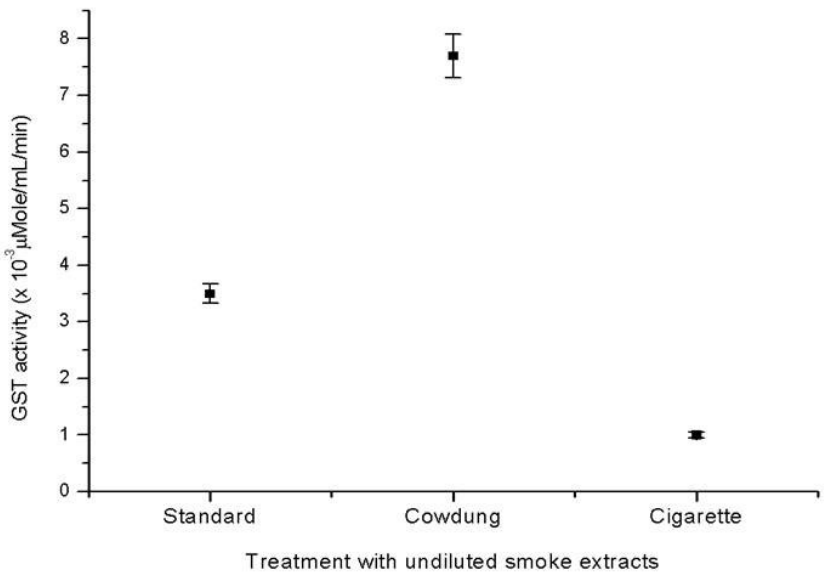

Fig. 6. Estimation of GST activity in PBMCs exposed to cowdung smoke extract and CSE. The amount of $2 \times 10^{6}$ cells $/ \mathrm{mL}$ PBMCs were treated with cowdung smoke extract and CSE for $1 \mathrm{~h}$ at room temperature. Standard was included from HiMedia kit.

Variance (ANOVA) followed by Tukey's multiple comparison test could testify that the protection offered by (GlcNAc) ${ }_{2}$ towards CSE and cowdung smoke extract was indeed significant with a correlation coefficient 0.99 and $p<0.05$.

\section{Estimation of GST activity}

To support the cell viability and comet assay data, we 
estimated the GST activity in PBMCs exposed to cowdung smoke extract and CSE (Fig. 6). The GST, being glutathione dependent and the first-line endogenous antioxidative enzyme, plays a crucial role in understanding the redox state of cell. GST activity was 7.7 times higher in PBMCs exposed to cowdung smoke extract than CSE, which further suggests that cowdung smoke is posing less oxidative stress on PBMCs than cigarette smoke. Similarly, Basak et al. (2010) reported an elevated GST activity in rat liver cells exposed to biomass smoke and cigarette smoke. Lower values of GST observed in PBMCs exposed to CSE might be due to the exhaustion and rapid consumption of this enzyme to combat against free radicals generated during oxidative stress.

\section{Conclusions}

This study demonstrates the protective effect of $(\text { GlcNAc })_{2}$ towards cowdung and cigarette smoke induced DNA damage in PBMCs. This is important as those who are at a threat of exposure to smoke from cigarette or from burning cowdung as a biomass fuel, may be protected from severe toxic effects by preventive measures using $(\mathrm{GlcNAc})_{2}$. Smoke extracts from sawdust and wood did not show high DNA damage although they both decreased viability of PBMCs. This could be due to a short time $(1 \mathrm{~h})$ exposure of PBMCs to smoke extracts. Apparently, oxidative DNA damage due to cigarette and cowdung smoke with the same exposure time $(1 \mathrm{~h})$ is more harmful than other biomass fuels used in this study. Thus we can discourage the use of cowdung as a biomass fuel, which is presently used in rural and underdeveloped sections of several countries. $(\mathrm{GlcNAc})_{2}$ may be considered as a potential therapeutic agent for conferring protection from oxidative DNA damage.

\section{Acknowledgements}

This study was supported by Department of Science and Technology (DST), New Delhi, Government of India, through the research grant (Grant No. SR/S0/HS/0022/ 2011). NS is thankful to DST for Junior Research Fellowship. This study was partly funded by Swedish International Development Cooperation Agency (SIDA), Sweden, under the grant number AKT-2012-005. The authors are also thankful to Dr. D.Y. Patil Vidyapeeth, Pune, for the necessary infrastructure and support.

\section{References}

Azam M.S., Kim E.J., Yang H.S. \& Kim J.K. 2014. High antioxidant and DNA protection activities of $\mathrm{N}$-acetylglucosamine (GlcNAc) and chitobiose produced by exolytic chitinase from Bacillus cereus EW5. Springerplus 3: 354 .

Balakrishnan K., Sambandam S., Ramaswamy P., Mehta S. \& Smith K.R. 2004. Exposure assessment for respirable particulates associated with household fuel use in rural districts of Andhra Pradesh, India. J. Expo. Anal. Environ. Epidemiol. 14: S14-S25.

Basak S.S., Silig Y. \& Dogan O.T. 2010. Effects of the exposed to biomass and cigarette smoke on antioxidant defense system, GST activity and GSH levels in rat liver. The $3^{\text {rd }}$ Inter- national Congress on Cell Membranes and Oxidative Stress: Focus on Calcium Signaling and TRP Channels, 22-27 June 2010, Isparta, Turkey.

Bazzini C., Rossettia V., Antonio D., Civello D.A., Sassone F., Vezzoli V., Persani L., Tiberio L., Lanata L., Bagnasco M., Paulmichl M. \& Meyer G. 2013. Short- and long- term effects of cigarette smoke exposure on glutathione homeostasis in human bronchial epithelial cells. Cell. Physiol. Biochem. 32: $129-145$.

Bolling A.K., Totlandsdal A.I., Sallsten G., Braun A., Westerholm R., Bergvall C., Boman J., Dahlman H.J., Sehlstedt M., Cassee F., Sandstrom T., Schwarze P.E. \& Herseth J.I. 2012. Wood smoke particles from different combustion phases induce similar pro-inflammatory effects in a co-culture of monocyte and pneumocyte cell lines. Part. Fibre Toxicol. 9: 45.

Boot R.G., Blommaart E:F., Swart E., van der Ghauharali V.K., Bijl N., Moe C., Place A. \& Aerts J.M.F.G. 2001. Identification of a novel acidic mammalian chitinase distinct from chitotriosidase. J. Biol. Chem. 276: 6770-6778.

Bruce N., Neufeld L., Erick B.O. \& West C. 1998. Indoor biofuel air pollution and respiratory health: the role of confounding factors among women in highland Guatemala. Int. J. Epidemiol. 27: 454-458.

Campbell M.A., Golub M.S., Iyer P., Kaufman F.L., Li L.H., Messan M.F., Morgan J.E. \& Donald J.M. 2009. Reduced water intake: implications for rodent developmental and reproductive toxicity studies. Birth Defects Res. B Dev. Reprod. Toxicol. 86:157-157.

Castillo S.S., Levy M., Thaikoottathil J.V. \& Goldkorn T. 2007. Reactive nitrogen and oxygen species activate different sphingomyelinases to induce apoptosis in airway epithelial cells. Exp. Cell Res. 313: 2680-2686.

Ceylan E., Kocyigit A., Gencer M., Aksoy N. \& Selek S. 2006. Increased DNA damage in patients with chronic obstructive pulmonary disease who had once smoked or been exposed to biomass. Respir. Med. 100: 1270-1276.

Chen A.S., Taguchi T., Sakai K., Kikuchi K., Wang M.W. \& Miwa I. 2003. Antioxidant activities of chitobiose and chitotriose. Biol. Pharm. Bull. 26: 1326-1330.

Downs C.A., Montgomery D.W. \& Merkle C.J. 2011. Age-related differences in cigarette smoke extract-induced $\mathrm{H}_{2} \mathrm{O}_{2}$ production by lung endothelial cells. Microvasc. Res. 82: 311-317.

Forchhammer L., Moller P., Riddervold I.S., Bonlokke J., Massling A., Sigsgaard T. \& Loft S. 2012. Controlled human wood smoke exposure: oxidative stress, inflammation and microvascular function. Part. Fibre Toxicol. 9: 7.

Fullerton D.G., Bruce N. \& Gordon S.B. 2008. Indoor air pollution from biomass fuel smoke is a major health concern in the developing world. Trans. R. Soc. Trop. Med. Hyg. 102: 843-851.

Gyori B.M., Venkatachalam G., Thiagarajan P.S., Hsu D. \& Clement M.V. 2014. OpenComet: an automated tool for comet assay image analysis. Redox Biol. 2: 457-465.

Holz O., Jorres R., Kastner A. \& Magnussen H. 1995. Differences in basal and induced DNA single-strand breaks between human peripheral monocytes and lymphocytes. Mutat. Res. 332: $55-62$.

Hopkins J.M. \& Evans H.J. 1980. Cigarette smoke-induced DNA damage and lung cancer risks. Nature 283: 388-390.

Létuvé S., Kozhich A., Humbles A., Brewah Y., Dombret M.C. Grandsaigne M. \& Pretolani M. 2010. Lung chitinolytic activity and chitotriosidase are elevated in chronic obstructive pulmonary disease and contribute to lung inflammation. Am. J. Pathol. 176: 638-649.

Liang T.W., Chen Y.J., Yen Y.H. \& Wang S.L. 2007. The antitumor activity of the hydrolysates of chitinous materials hydrolyzed by crude enzyme from Bacillus amyloliquefaciens V656. Process Biochem.42: 527-534.

Mates J.M., Segura J.A., Alonso F.J. \& Marquez J. 2012. Oxidative stress in apoptosis and cancer: an update. Arch. Toxicol. 86: $1649-1665$.

Musonda C.A. \& Chipman J.K. 1998. Quercetin inhibits hydrogen peroxide $\left(\mathrm{H}_{2} \mathrm{O}_{2}\right)$-induced $\mathrm{NF}-\kappa \mathrm{B}$ DNA binding activity and DNA damage in HepG2 cells. Carcinogenesis 19: 15831589 . 
Nawani N.N., Prakash D. \& Kapadnis B.P. 2010. Extraction, purification and characterization of an antioxidant from marine waste using protease and chitinase cocktail. World J. Microbiol. Biotechnol. 26: 1509-1517.

Ngo D.N., Kim M.M., Qian Z.J., Jung W.K., Lee S.H. \& Kim S.K. 2010. Free radical scavenging activities of low molecular weight chitin oligosaccharides lead to antioxidant effect in live cells. J. Food Biochem. 34: 161-177.

Ozturk S., Vatansever S., Cefle K., Palanduz S., Guler K., Erten N., Erk O., Karan M.A. \& Tascioglu C. 2002. Acute wood or coal exposure with carbon monoxide intoxication induces sister chromatid exchange. J. Toxicol. Clin. Toxicol. 40: 115120.

Prakash M., Bodas M., Prakash D., Nawani N., Khetmalas M., Mandal A. \& Eriksson C. 2013. Diverse pathological implications of YKL-40: answers may lie in 'outside-in' signaling. Cell. Signal. 25:1567-1573.

Rekhadevi P.V., Mahboob M., Rahman M.F. \& Grover P. 2009. Genetic damage in wood dust-exposed workers. Mutagenesis 24: 59-65.

Salgaonkar N., Prakash D., Nawani N.N. \& Kapadnis B. P. 2015. Comparative studies on ability of $N$-acetylated chitooligosaccharides to scavenge reactive oxygen species and protect DNA from oxidative damage. Indian J. Biotechnol. 14: 186-192.

Singh N.P., McCoy M.T., Tice R.R. \& Schneider E.L. 1988. A simple technique for quantification of low levels of DNA damage in individual cells. Exp. Cell Res. 175: 184-191.

Slezak M., Skalniak A., Groszek B., Piatkowski J. \& Pach D. 2014. The effect of acute carbon monoxide poisoning on micronuclei frequency and proliferation in human peripheral blood lymphocytes (case-control study). Przegl. Lek. 71: $463-468$.

Smith K.R. 1993. Fuel combustion, air-pollution exposure and health: the situation in developing countries. Annu. Rev. Energy Environ. 18: 529-566.
Smith K.R. 2003. Indoor air pollution implicated in alarming health problems. In: Indoor Air Pollution - Energy and Health for Poor. News Letter 1.

Smith K.R. \& Liu Y. 1994. Indoor air pollution in developing countries, pp.151-184. In: Samet J.M. (ed.), Epidemiology of Lung Cancer. Lung Biology in Health and Disease, Marcel Dekker, New York.

Smith K.R., Mehta S. \& Maeusezahl-Feuz M. 2004. Indoor air pollution from household use of solid fuels: comparative quantification of health risks. In: Ezzati M., Rodgers A.D., Lopez A.D. \& Murray C.J.L. (eds), Comparative Quantification of Health Risks: Global and Regional Burden of Disease due to Selected Major Risk Factors, World Health Organization, Geneva, Switzerland.

Smith K.R., Samet J.M., Romieu I. \& Bruce N. 2000. Indoor air pollution in developing countries and acute lower respiratory infections in children. Thorax 55: 518-532.

Wang S.L., Hsu W.H. \& Liang T.W. 2010. Conversion of squid pen by Pseudomonas aeruginosa K-187 fermentation for the production of $N$-acetyl chitooligosaccharides and biofertilizers. Carbohydr. Res. 345: 880-885.

Wang S.L., Yang C.W., Liang T.W. Peng J.H. \& Wang C.L. 2009. Degradation of chitin and production of bioactive materials by bioconversion of squid pens. Carbohydr. Polym. 78: 205212.

WHO. 2000. Air quality guidelines for Europe. WHO regional publications, 91. Copenhagen, Denmark.

WHO. 2009. Global health risks: mortality and burden of disease attributable to selected major risks. WHO publications, Geneva, Switzerland.

WHO. 2011. Indoor air pollution and health: fact sheet No. 292. WHO publications, Geneva, Switzerland.

WHO. 2014. WHO indoor air quality guidelines: household fuel combustion. WHO publications, Geneva, Switzerland.

Received December 31, 2015 Accepted May 9, 2016 